Journal of Marine Research

May 2008 ; Volume 66, Number 3 : Pages 347-372

http://dx.doi.org/10.1357/002224008786176034

(C) 2008 Sears Foundation for Marine Research, Yale University
Archimer

Archive Institutionnelle de l'Ifremer http://www.ifremer.fr/docelec/

http://www.journalofmarineresearch.org/

\title{
Hydrography and flow in the Lucky Strike segment of the Mid-Atlantic Ridge
}

\author{
A. M. Thurnherr ${ }^{1},{ }^{*}$, G. Reverdin ${ }^{2}$, P. Bouruet-Aubertot ${ }^{2}$, L. C. St. Laurent ${ }^{3}$, \\ A. Vangriesheim ${ }^{4}$ and $\mathrm{V}$. Ballu ${ }^{5}$
}

\footnotetext{
${ }^{1}$ Lamont-Doherty Earth Observatory, Columbia University, Palisades, NY, USA

${ }^{2}$ LOCEAN, UMR7159 CNRS/UPMC/IRD/MNHN, Université Pierre et Marie Curie, Paris, France

${ }^{3}$ Dept. of Oceanography, Florida State University, Tallahassee, FL, USA

4 Ifremer, DEEP/LEP, BP70, 29280 Plouzané, France

${ }^{5}$ PGP/CNRS, 4 place Jussieu, 75252 Paris cedex 05, France (now at IRD/CNRS, Geoazur, Port-Vila, Vanuatu)
}

*: Corresponding author : A. M. Thurnherr, email address : ant@ldeo.columbia.edu

\begin{abstract}
:
The Lucky Strike segment between 37 and $38 \mathrm{~N}$ on the Mid-Atlantic Ridge is the focus of the international MoMAR program to monitor seafloor-spreading processes. During the GRAVILUCK cruise in August 2006, hydrographic, velocity and light-scattering data were collected in the rift valley at Lucky Strike in order to investigate the regional dynamics and to provide background information for the monitoring effort. The survey observations reveal a remarkably simple dynamical setting dominated by persistent northward flow transporting $\approx 0.2 \mathrm{~Sv}$ of water along the rift valley. Approximately half of this transport must upwell within a deep basin that occupies the northern half of the segment. In the comparatively shallow segment center, the along-valley transport takes place in two parallel, hydraulically controlled overflows on both sides of an active volcano that rises from the rift-valley floor. Within the better sampled of these overflows instantaneous velocities recorded during the survey were northward more than $95 \%$ of the time and occasionally exceeded $20 \mathrm{~cm} \mathrm{~s}^{-1}$. Similar to other laterally confined overflows in the deep ocean, the cross-sill density gradients are characterized by a lower layer with streamwise decreasing densities and an upper layer where the densities increase along the path of the flow. This vertical density-gradient dipole is the signature of the buoyancy flux associated with high levels of diapycnal mixing near the sill. Overall, the hydrography and dynamics in the rift valley of the Lucky Strike segment are highly reminiscent of many ridge-flank canyons in the western South Atlantic, where mean along-axial advection of density is balanced by vigorous diapycnal mixing. There is circumstantial evidence from historic hydrographic data suggesting that northward flow below $\approx 1800 \mathrm{~m}$ in the rift valley in the MoMAR region is persistent on time scales of years to decades and that it extends more than $200 \mathrm{~km}$ to the south. During GRAVILUCK the northward flow at Lucky Strike extended well above $1600 \mathrm{~m}$, where two previous one year-long current meters had recorded southward mean flows near the Lucky Strike hydrothermal vent field. While interannual variability can potentially account for this difference, the data also allow for the possibility of a cyclonic re-circulation around an isolated topographic peak east of the vent field, resulting in the southward mean flows observed there. In addition to the light-scattering anomalies associated with plumes rising from the Lucky Strike vent field near the segment center, the GRAVILUCK data also show clear evidence for a separate hydrothermal particle plume emanating from a not-yet-discovered vent field in the southern half of the segment, probably near $2000 \mathrm{~m}$.
\end{abstract}




\section{Introduction}

Hydrothermal circulation accounts for approximately one third of the global geothermal heat flux to the oceans and strongly affects the chemical composition of the water (e.g. Elderfield and Schultz, 1996). Most of the currently known hydrothermal sources in the ocean occur along the axes of mid-ocean ridges where tectonic plates spread apart and new seafloor is formed (e.g. Baker and German, 2004). The chemical energy associated with hydrothermal effluents supports chemosynthetic ecosystems that are characterized by a high degree of endemicity (e.g. Herring, 2002). Hydrothermal vent fields typically contain many individual sources from which the hot effluents rise as buoyant plumes through the water column. Entrainment and mechanical mixing driven by other processes increase the density of the rising effluents until the plumes reach their 


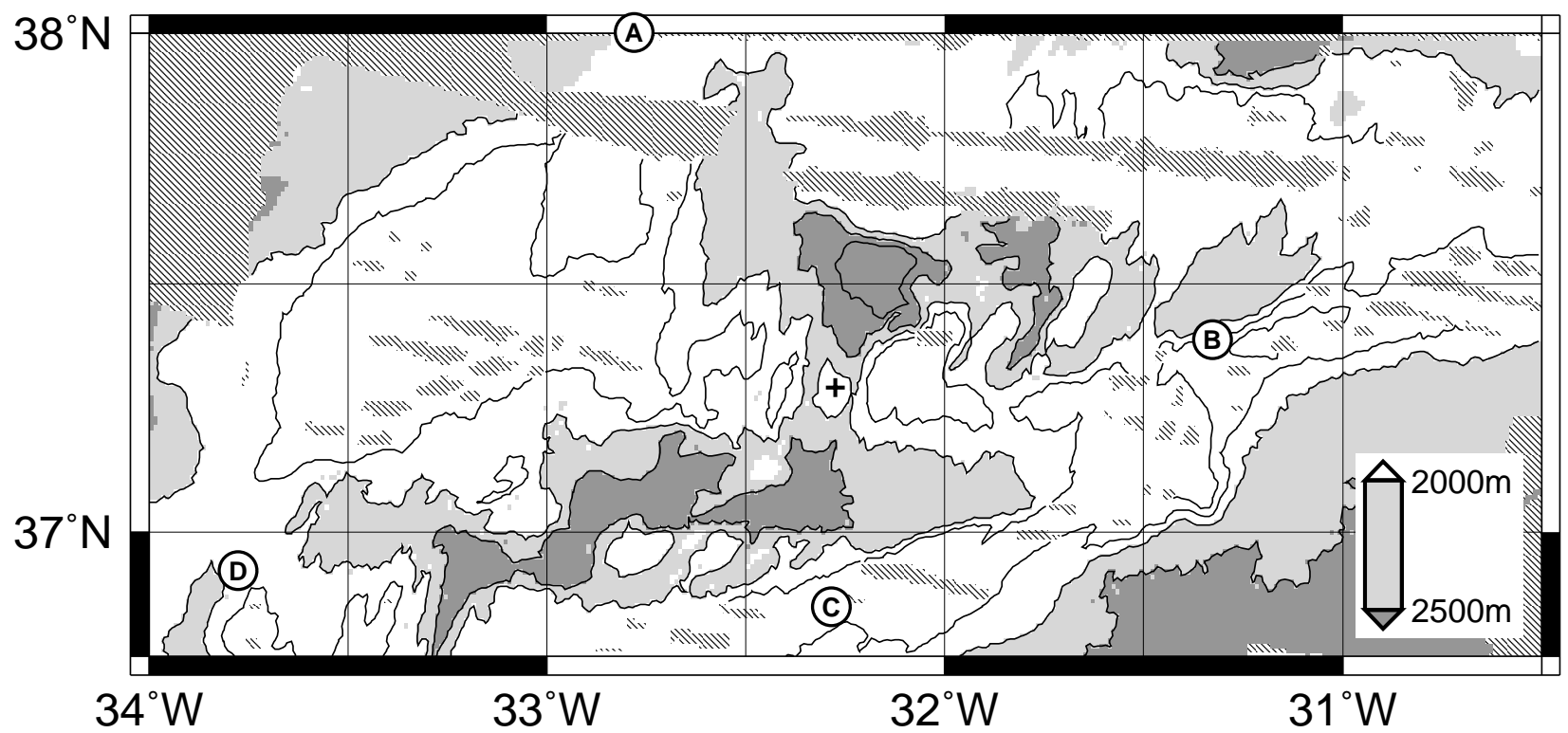

Figure 1: Lucky Strike segment topography, from Cannat et al. (1999); contour interval is $500 \mathrm{~m}$; hatched areas are regions of no data. The cross at $37^{\circ} 18^{\prime} \mathrm{N} 32^{\circ} 17^{\prime} \mathrm{W}$ marks the location of the Lucky Strike vent field. Circled labels indicate sills that connect the rift valley to the ridge flanks, as determined with the algorithm of Otto and Thurnherr (2007); sill depths, rounded to $10 \mathrm{~m}$ : A: $1790 \mathrm{~m}, \mathrm{~B}: 1080 \mathrm{~m}, \mathrm{C}: 1310 \mathrm{~m}$ and D: $1830 \mathrm{~m}$.

levels of neutral buoyancy, where they are dispersed laterally by the oceanic currents (e.g. McDuff, 1995).

While hydrothermal fluxes of energy and mass can be determined from measurements at the vents (e.g. Converse et al., 1984), the distributed nature of hydrothermal sources makes vent-fieldscale flux estimates using this method difficult and costly. Neutrally buoyant hydrothermal plumes, on the other hand, integrate the effects of multiple temporally varying and spatially distributed sources. Due to their high load of suspended particles, neutrally buoyant plumes from hightemperature hydrothermal sources can be mapped by carrying out optical water-column surveys near hydrothermal vent fields. Such plume observations have been used to quantify hydrothermal heat fluxes (e.g. Thurnherr and Richards, 2001) as well as to characterize dispersal of a variety of hydrothermal "products," including geochemical tracers (e.g. Jean-Baptiste et al., 1998) and larvæ of organisms associated with hydrothermal vent-field ecosystems (e.g. Mullineaux et al., 1995). In order to calculate fluxes from neutrally buoyant hydrothermal-plume observations, both the hydrography and the circulation that disperses the plumes must be known.

Here, we report on the results from a recent survey of the hydrography, velocity field, and light scattering in the rift valley of the Lucky Strike segment of the Mid-Atlantic Ridge (MAR). The known hydrothermal sources are located on a seamount in the segment center near $37^{\circ} 18^{\prime} \mathrm{N}$ $32^{\circ} 17^{\prime} \mathrm{W}$ (Langmuir et al., 1997; Fig. 1). The Lucky Strike site is the focus of the interdisciplinary 
international MoMAR project to monitor seafloor-spreading processes on the MAR ${ }^{1}$. As is typically the case for hydrothermal vent fields on slow-spreading mid-ocean ridges, the Lucky Strike vents lie deep inside the rift valley, which is physically isolated from the water column on the MAR flanks: With the exception of a passage at $1310 \mathrm{~m}$ near the southern end of the segment (labeled "C" in Fig. 1), the eastern rift-valley wall blocks exchange between the rift valley and the deep eastern North Atlantic up to a depth of $\approx 1100 \mathrm{~m}$. In the west, the Lucky Strike rift valley is connected to the open North Atlantic via two deeper passages: Passage " $\mathrm{A}$ " in the northwest at $1790 \mathrm{~m}$ and passage "D" in the southwest at $1830 \mathrm{~m}$.

Ours are not the first water-column data collected in the Lucky Strike segment: During the FAZAR cruise in 1992 a number of quasi-horizontal tows and vertical casts with hydrographic, optical and geochemical sensors were carried out near the Lucky Strike vent field, which had been discovered during the same cruise (Langmuir et al., 1997). During FAZAR, the neutrally buoyant hydrothermal plumes from the Lucky Strike vents were associated with weak (compared to other hydrothermal sites on the MAR) optical particle signatures and spanned the depth range between 1350 and $1900 \mathrm{~m}$. Except for some small optical anomalies directly over the seamount, the hydrothermal signatures in the Lucky Strike segment were restricted to depths below $1400 \mathrm{~m}$ (Wilson et al., 1996), i.e. the hydrothermal plumes were largely confined within the rift valley, as is usually the case for hydrothermal plumes rising from vent fields on slow-spreading ridges (German et al., 1995). Since the hydrothermal plumes in the FAZAR data extend significantly below the depth of the known vents $(\approx 1700 \mathrm{~m})$, an additional, not-yet-discovered hydrothermal source has been hypothesized to lie somewhere near the base of the seamount (Klinkhammer et al., 1995; Wilson et al., 1996). In 1994, two years after FAZAR, additional hydrographic and optical data were collected in the Lucky Strike segment during the HEAT cruise (German et al., 1996). Due to instrument and sampling limitations the plume in the segment center was missed by two horizontal tows, but a clear optical plume signal centered near $1800 \mathrm{~m}$ was observed $\approx 25 \mathrm{~km}$ south of the seamount at $37^{\circ} 03^{\prime} \mathrm{N} 32^{\circ} 25^{\prime} \mathrm{W}$. German et al. (1996) attribute this plume to another not-yet-discovered hydrothermal source.

In terms of the hydrography at Lucky Strike, Wilson et al. (1995) note that the T/S properties observed in the rift valley in 1992 (FAZAR) were characterized by salinity-compensated temperature inversions up to $\approx 0.05^{\circ} \mathrm{C}$ (the corresponding salinity anomalies are $\approx 0.01$ ), presumably associated with frontal interleaving. The isopycnal temperature and salinity variability associated with these interleaving signatures largely masks the hydrographic anomalies associated with the hydrothermal plumes $\left(\Delta \theta \approx 0.02^{\circ} \mathrm{C}\right.$; Wilson et al., 1996).

Approximately three months before the 1994 water-column survey (HEAT) was carried out, two moorings with a total of three current meters were deployed in close proximity to the hydrothermal vents (Jean-Baptiste et al., 1998; Khripounoff et al., 2000). The taller of the moorings was deployed for a total of 14 months with current meters 20 and $130 \mathrm{~m}$ above the seabed. The velocity records from both instruments are dominated by very strong semidiurnal tidal fluctuations, with respective maximum speeds of 23 and $29 \mathrm{~cm} \mathrm{~s}^{-1}$. Both instruments recorded predominantly along-valley (approximately meridional) flow. In the record from the lower instrument, which failed after 95 days, the current was persistently to the north, with a mean speed of $2.9 \mathrm{~cm} \mathrm{~s}^{-1}$. The

\footnotetext{
${ }^{1}$ http://www.ipgp.jussieu.fr/rech/lgm/MOMAR
} 
upper instrument recorded several flow reversals; the 408 days record mean is $1.5 \mathrm{~cm} \mathrm{~s}^{-1}$ to the south-southwest. Due to an instrument problem, the single current meter deployed on the shorter mooring about $3.5 \mathrm{~m}$ above the seabed did not record current speed — during its 25-day deployment the flow direction was predominantly between north- and eastward (Khripounoff et al., 2000).

This paper is organized as follows: Section 2 contains a description of the rift-valley topography, instrumentation and data processing, as well as the survey design. The main hydrographic and circulation observations are presented and analyzed in Section 3. In Section 4 the optical signatures of two distinct hydrothermal particle plumes in the Lucky Strike segment are described. The paper concludes with a synthesis and discussion of our observations (Section 5).

\section{Methods}

\section{a. Rift-Valley Topography}

The topography of the Lucky Strike segment is characterized by an hour-glass-shaped rift valley, consisting of two deep $(>2700 \mathrm{~m})$ segment-end basins connected by a narrower and shallower region in the segment center, where the rift valley trends approximately N-S $\left(20^{\circ}\right.$ true; Fig. 1$)$. The volcanically active Lucky Strike seamount rises from the valley floor in the segment center, leaving two narrow and almost equally deep passages connecting the southern and northern basins on both sides of the seamount (Fig. 2). The sill depths and approximate minimum channel widths are $2060 \mathrm{~m} / 5 \mathrm{~km}$ and $2075 \mathrm{~m} / 3 \mathrm{~km}$ for the western and eastern passages, respectively. Near the sills, both passages are confined below $\approx 1700 \mathrm{~m}$ by extremely steep lateral walls, with multibeam data indicating slopes of $\approx 0.5$ (rise/run). The top of the seamount consists of two groups of peaks separated by a $1775 \mathrm{~m}$ deep passage. (The individual peaks are not visible in Fig. 2; for a closeup of the eastern group, see Fig. 11 below.) The highest peak in the western group rises to a depth of $1540 \mathrm{~m}$ near $37^{\circ} 19.2^{\prime} \mathrm{N} 32^{\circ} 18.2^{\prime} \mathrm{W}$ and the highest peak in the eastern group rises to a depth of $1560 \mathrm{~m}$ near $37^{\circ} 17.1^{\prime} \mathrm{N} 32^{\circ} 16.9^{\prime} \mathrm{W}$. The known hydrothermal vents at Lucky Strike are situated between the peaks of the eastern group near $37^{\circ} 17.5^{\prime} \mathrm{N} 32^{\circ} 16.5^{\prime} \mathrm{W}$ at depths ranging from 1646 to $1706 \mathrm{~m}$ (Langmuir et al., 1997).

\section{b. Instrumentation and Data Processing}

In August 2006 the French research vessel L'Atalante visited the Lucky Strike segment, primarily in order to install a geodesy network for monitoring vertical deformation of the seafloor (GRAVILUCK project). A separate physical oceanographic component, funded by the US National Science Foundation with additional support from the French government, was carried out during alternate nights of the twenty-day expedition. The survey consisted primarily of CTD, LADCP and microstructure casts, augmented by a 2-week deployment of a bottom-mounted ADCP. This paper discusses primarily the hydrographic and velocity data; results from the microstructure component of the project have been reported elsewhere (St. Laurent and Thurnherr, 2007).

The main profiling platform used during the survey was a SBE 911 CTD mounted on a frame together with a 24-bottle rosette, a Teledyne/RDI Workhorse $300 \mathrm{kHz}$ ADCP and a high-sensitivity 


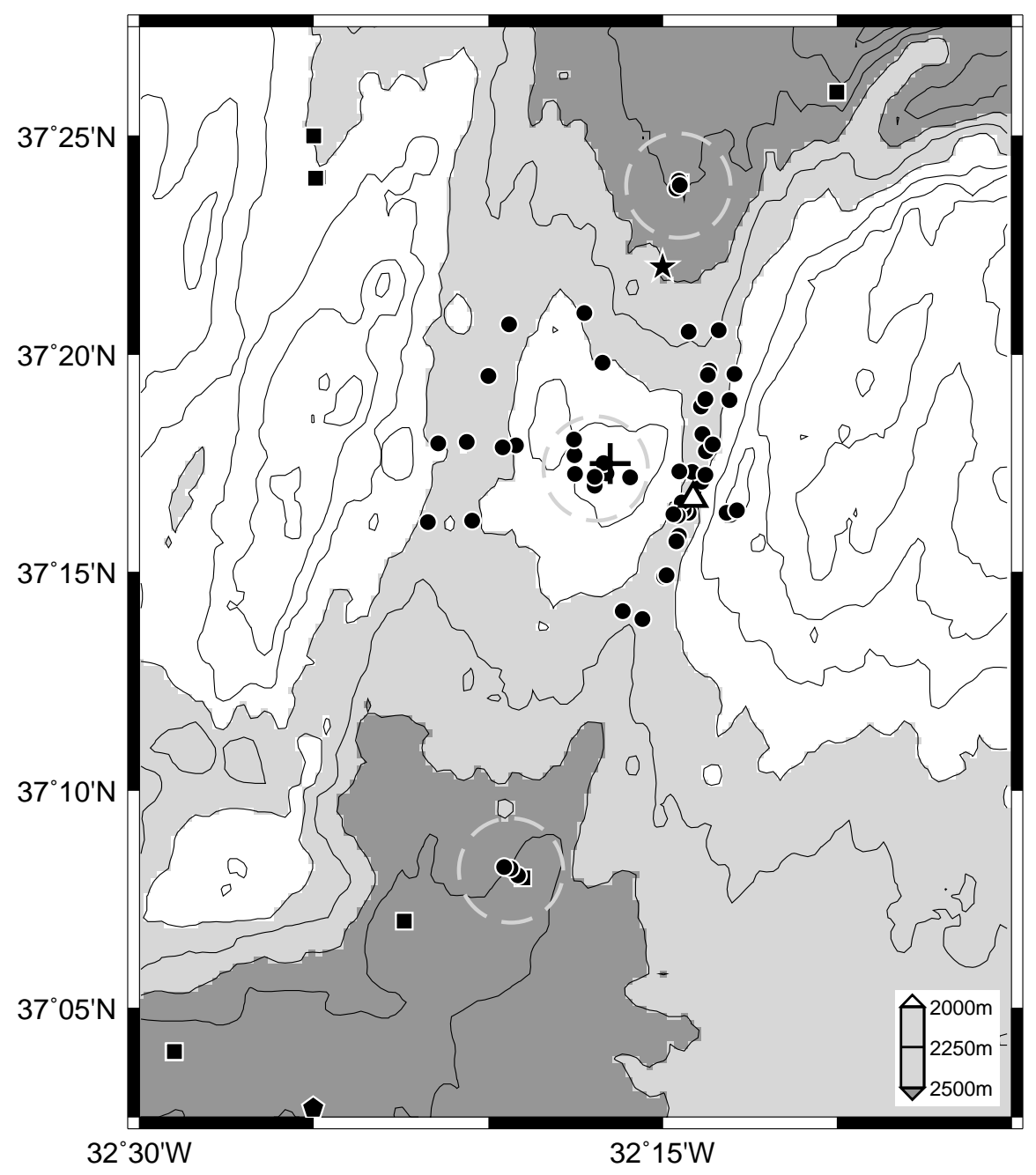

Figure 2: Hydrographic stations in the Lucky Strike segment; topographic contour interval is $250 \mathrm{~m}$. The cross at $37^{\circ} 18^{\prime} \mathrm{N} 32^{\circ} 17^{\prime} \mathrm{W}$ marks the location of the Lucky Strike vent field; the triangle at $37^{\circ} 17^{\prime} \mathrm{N} 32^{\circ} 14^{\prime} \mathrm{W}$ shows the deployment location of the bottom-mounted ADCP. Bullets: L'Atalante CTD/LADCP/STM stations; squares: Pourquoi Pas ? CTD stations; star at $37^{\circ} 22^{\prime} \mathrm{N}$ $32^{\circ} 15^{\prime} \mathrm{W}$ : location of two CTD profiles collected in 2005 (EXOMAR cruise); pentagon at $37^{\circ} 03^{\prime} \mathrm{N}$ $32^{\circ} 25^{\prime} \mathrm{W}$ : plume station of German et al. (1996). Dashed circles enclose the L'Atalante stations from which mean light-scattering (STM) profiles were constructed (Section 4).

(5 FTU range) version of the Seapoint Turbidity Meter (STM), measuring the backscatter of light from suspended particles in the water column. Additional full-depth CTD profiles were collected with a self-contained SBE 19+ from a second French research vessel, the Pourquoi Pas ?, which carried out a separate project in the Lucky Strike region at the same time.

The primary CTD (SBE 911) was equipped with sensors for pressure, temperature, conductivity and partial pressure of oxygen. The oxygen sensor calibration was not verified with water 
samples; as a result, the accuracy of the oxygen data is not known. Temperature and conductivity were recorded with two thermistors and two conductivity cells, respectively. The sensors known to perform better were used as primaries. The salinities derived from the two temperature and conductivity sensor pairs are very similar (usually within 0.001 of each other), and the salinity calibration was monitored with water samples analyzed on a Guildline Autosal salinometer. The accuracy of the salinity data, determined from the Autosal measurements and supported by a postcruise conductivity-sensor calibration, is $\approx 0.001$. The temperature and pressure sensors were also post-cruise calibrated, yielding accuracies of $0.001^{\circ} \mathrm{C}$ and $0.5 \mathrm{dbar}$ respectively.

The secondary CTD (SBE 19+) was equipped with one sensor each for pressure, temperature and conductivity. The salinity bias of the secondary CTD was evaluated by comparisons with data from the primary CTD in the deep basin south of the Lucky Strike seamount between 2500 and $2700 \mathrm{~m}$, where the mean isobaric standard deviation of salinity reaches a minimum of $1.5 \times 10^{-4}$. Both salinity vs. depth and salinity vs. potential temperature indicate an identical salinity bias of -0.007 in the secondary CTD, which implies that there is no significant bias in the SBE 19+ temperature data. The success of the salinity-bias correction is confirmed by the observation that the isobaric potential-density standard deviation in the deep basin south of the segment center for a mean profile derived from both CTDs ( 7 profiles collected over 11 days; $\left.2.3( \pm 0.6) \times 10^{-4}\right)$ is similar to the corresponding standard deviation calculated from the primary CTD alone (3 profiles collected over 12 hours; $1.4( \pm 0.6) \times 10^{-4}$ ), whereas the corresponding standard deviation of the combined data set before bias correction is more than an order of magnitude larger $\left(29.3( \pm 0.6) \times 10^{-4}\right)$.

The light-scattering data from all our rift-valley profiles are associated with local minima between 850 and $950 \mathrm{~m}$. In order to correct for cast-to-cast variability in the instrument response, e.g. due to dirt on the sensor window, the median instrument response of each cast in this depth range was used as a reference value for the profile, yielding the light-scattering anomalies used below.

The LADCP was programmed to record single-ping velocity ensembles in beam coordinates. The blanking distance was set to $0 \mathrm{~m}$ and data from the first bin were discarded. In order to minimize the effects of previous-ping interference, staggered pings $(1 \mathrm{~s} / 1.6 \mathrm{~s})$ were used. Initially the bin length was set to $4 \mathrm{~m}$. During the first few casts proximity of the CTD/LADCP platform to the seabed was determined using a bottom switch, triggered by a steel ball suspended on a wire below the CTD frame. However, it was soon found that the acoustic reflections from the steel ball significantly degraded the LADCP data quality and the switch was removed after station 12. During testing the ADCP was swapped with a spare after station 4 and the spare was left on during the remainder of the cruise because of its more audible ping. On station 14, the bin length was doubled to $8 \mathrm{~m}$ in order to increase the range and, thus, the data quality and this setup was kept for the remainder of the survey. The LADCP data from the casts carried out with the CTD bottom switch are not used here.

The LADCP data were processed both with the shear-method implementation of the University of Hawaii ${ }^{2}$ and with the Lamont inversion software ${ }^{3}$. The former uses the GPS-derived ship drift to constrain the barotropic velocities whereas the latter additionally makes use of shipboard ADCP

\footnotetext{
${ }^{2}$ http://currents.soest.hawaii.edu/software/ladcp

${ }^{3} \mathrm{ftp}: / / \mathrm{ftp}$.ldeo.columbia.edu/pub/LADCP/Version_IX
} 


\begin{tabular}{|l||rrrr|rrr|}
\hline project & depth & h.a.b. & rec. start & duration & $<$ dir. $>$ & $<$ speed $>$ & $\%$ northward \\
\hline \hline DIVA & $1570 \mathrm{~m}$ & $130 \mathrm{~m}$ & Jun 2, 1994 & 407 days & $201^{\circ}$ & $1.5 \mathrm{~cm} \mathrm{~s}^{-1}$ & $14-65 \%$ \\
ATOS & $1615 \mathrm{~m}$ & $15 \mathrm{~m}$ & Jul 4, 2001 & 364 days & $153^{\circ}$ & $2.8 \mathrm{~cm} \mathrm{~s}^{-1}$ & $18-41 \%$ \\
\hline
\end{tabular}

Table 1: Year-long current-meter data from the center of the Lucky Strike seamount; see Figure 11 for mooring locations. Angle brackets indicate record averages; h.a.b. is height above bottom; the column labeled "\% northward" lists the incidence of northward flow in non-overlapping 2-week data segments.

and bottom-tracking data. Except for the early casts when the bottom switch was in place, there is good agreement between the profiles processed with the two methods: The overall rms velocity difference calculated from the $20 \mathrm{~m}$ sub-sampled profiles without the bottom switch is $3.7 \mathrm{~cm} \mathrm{~s}^{-1}$, which agrees well with the corresponding mean inversion-derived velocity error of $3.4 \mathrm{~cm} \mathrm{~s}^{-1}$, and the average ratio of the flow speed to the magnitude of the velocity differences (signal-to-noise ratio) is 3.2. (For comparison, the corresponding signal-to-noise ratio for the casts with the bottom switch is only 1.4.) In many of the casts the instrument range (as calculated by the Lamont software) attains a minimum value of $\approx 75 \mathrm{~m}$ between 1500 and $1700 \mathrm{~m}$. The LADCP data presented below are inversion solutions.

During the GRAVILUCK cruise, a second $300 \mathrm{kHz}$ Teledyne/RDI Workhorse ADCP was deployed on the seabed for 14 days. It was mounted together with a battery case on a frame designed and constructed by the FSU current-meter facility. Since this package was deployed and recovered with the submersible Nautile it was possible to ensure that the instrument was oriented nearly vertically (pitch $<3.5^{\circ}$ ), at accurately known position $\left(32^{\circ} 14.12^{\prime} \mathrm{W}, 37^{\circ} 16.70^{\prime} \mathrm{N}\right)$ and depth $(2078 \mathrm{~m})$ and with unobstructed beam paths. The bottom-mounted ADCP was programmed to ping every $6 \mathrm{~s}$ and record 1-minute ensemble averages in beam coordinates. The bin length was set to $4 \mathrm{~m}$, the blanking distance to zero and the data from the first bin were discarded, as were all beam velocities determined from less than 3 samples. The instrument recorded complete velocity time series in the bottom $65 \mathrm{~m} ; 100 \mathrm{~m}$ above the seabed only $15 \%$ of the velocities remain valid. One of the beams performed significantly worse than the others, resulting in an increase of 3-beam solutions from $1 \% 40 \mathrm{~m}$ above bottom to $95 \% 100 \mathrm{~m}$ above the seabed.

In addition to the velocity data collected during the GRAVILUCK cruise, we also use 2 oneyear-long current-meter records collected in 1994/95 (DIVA project; Jean-Baptiste et al., 1998; Khripounoff et al., 2000) and 2001/02 (ATOS project; Khripounoff et al., 2008) - see Table 1 for details.

\section{c. Survey Design}

A substantial fraction of the physical oceanography sampling during GRAVILUCK was carried out in the eastern passage between the eastern flank of the Lucky Strike volcano and the eastern rift-valley wall (Fig. 2), primarily because of the somewhat simpler channel topography compared to the western passage. In order to account for tidal variability CTD/LADCP repeat 
profiles were collected during different phases of the semidiurnal tide (as determined from a precruise tidal analysis of the DIVA current-meter records). The 2-week averaged velocities recorded by the bottom-mounted ADCP near the eastern-passage sill is indistinguishable (within the uncertainties) from a corresponding ensemble-averaged LADCP profile constructed from 4 profiles taken during the same time interval within $500 \mathrm{~m}$ of the sill (see Fig. 8 below). Furthermore, the rms difference at $2000 \mathrm{~m}$ between the bottom-mounted ADCP velocities and the individual LADCP casts $\left(4.2 \mathrm{~cm} \mathrm{~s}^{-1}\right)$ is significantly larger than the corresponding velocity difference in the ensembleaveraged LADCP profile $\left(2.5 \mathrm{~cm} \mathrm{~s}^{-1}\right)$. These observations imply i) that tidal influence in the ensemble average is significantly reduced compared to individual profiles and ii) that the LADCP data are of high quality. Additional evidence supporting these inferences is provided by the consistency of the LADCP-derived circulation near the Lucky Strike seamount (see Section 3c below).

\section{Hydrography and Flow}

\section{a. Regional Hydrographic Setting}

Above the topography of the MAR, the regional hydrography near the Lucky Strike segment is dominated by the meandering Azores current/front, which forms the southern limit of the Mediterranean water tongue (Sy, 1988). Gould (1985) proposes two criteria to assess whether a given station lies north or south of the Azores Front, one for the depth of the $15^{\circ} \mathrm{C}$ isotherm and the other for the surface salinity: North of the front the $15^{\circ} \mathrm{C}$ isotherm is shallower than $300 \mathrm{~m}$, and typically found near $100 \mathrm{~m}$ - the corresponding mean value ( \pm 1 standard deviation) observed during GRAVILUCK is $250( \pm 50) \mathrm{m}$. The surface salinity north of the Azores front is less than 36.4 with typical values near 36.2 - the GRAVILUCK value is $36.4( \pm 0.1)$. Both criteria suggest that the southern edge of the frontal region was sampled. While it is not clear whether the criteria of Gould (1985) remain valid - recent satellite and float observations indicate a regional warming near the surface of about $1^{\circ} \mathrm{C}$ compared to the $1980 \mathrm{~s}$ - our interpretation is consistent with the location of one of the branches of the Azores current apparent in satellite-altimetry data and with the fact that a strong salinity maximum associated with Mediterranean water (35.57 at $998 \mathrm{~m}$ ) was only observed in a single profile. While the MAR in our study region does not constitute a solid barrier for cross-ridge exchange above $1000 \mathrm{~m}$ (Fig. 1) its apparent influence on the hydrography extends throughout the entire layer of Mediterranean water, as evidenced by a westward cross-ridge salinity drop extending at least up to $700 \mathrm{~m}$ in this region (e.g. Wilson et al., 1995).

The hydrographic properties of the water within the rift valley are limited by the conditions at the inflow sills (Saunders and Francis, 1985; Thurnherr et al., 2002). In regions where there are appreciable along- or cross-ridge isopycnal gradients of hydrographic properties, such as temperature, salinity or oxygen, differences in rift-valley properties can be used to constrain the relative locations of different inflows. In our study region the deepest sills connecting the rift valley to the off-ridge water column are found at approximately $1800 \mathrm{~m}$ (Fig. 1), i.e. significantly below the core of the Mediterranean water. In order to assess the regional horizontal hydrographic gradients at this depth we use data from a 1983 survey (TOPOGULF/3; Harvey and Arhan, 1988), which consists of a $1000 \times 1000 \mathrm{~km}$ box of CTD stations centered on the ridge crest near $35^{\circ} \mathrm{N}$. The max- 

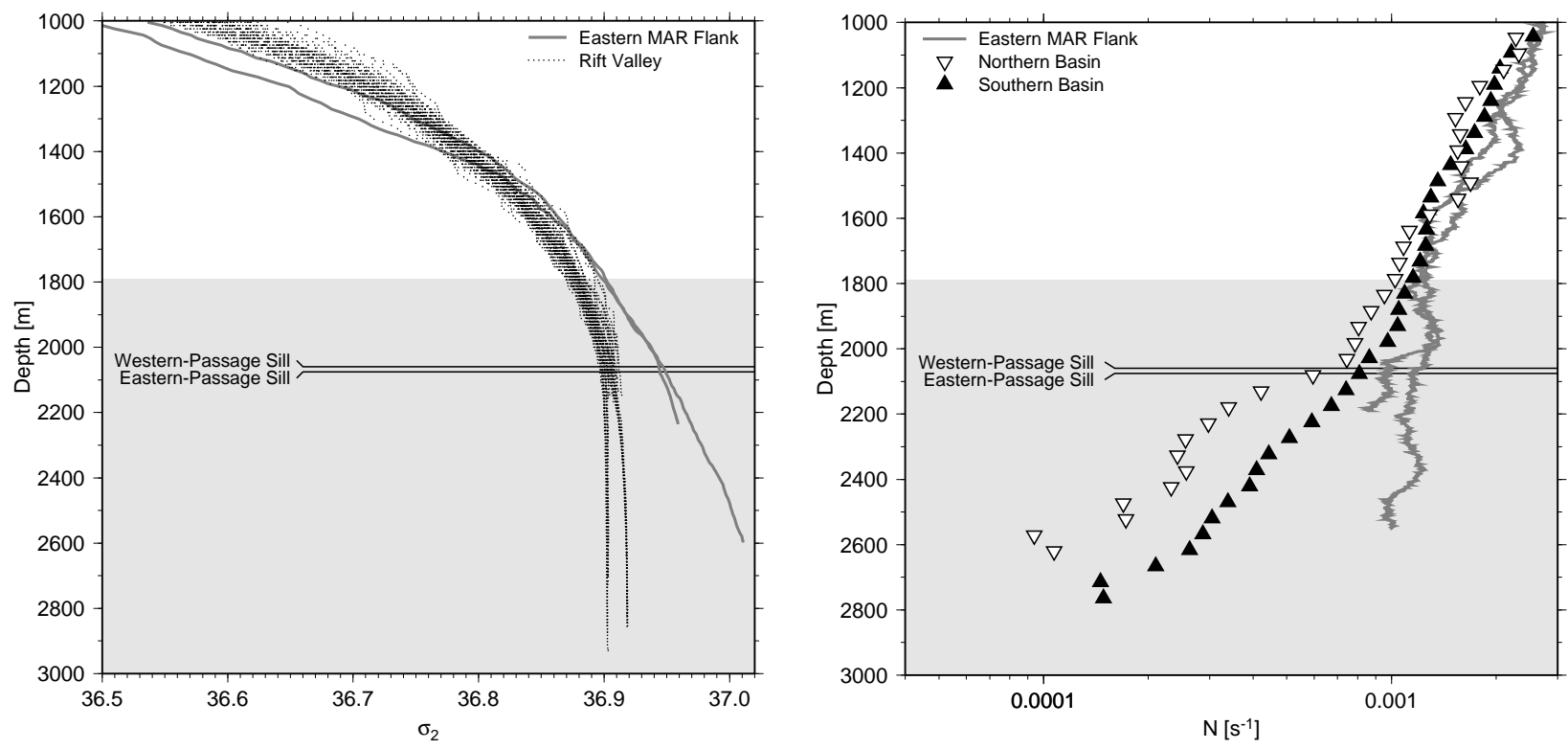

Figure 3: Density Stratification at Lucky Strike. Left panel: potential density; right panel: buoyancy frequency. Depths below deepest sills on the rift-valley walls are shaded; the horizontal lines indicate the sill depths in the two deep passages on either side of the Lucky Strike seamount. The two eastern-flank stations were occupied at $36^{\circ} 00^{\prime} \mathrm{N} 29^{\circ} 03^{\prime} \mathrm{W}$ and $37^{\circ} 06^{\prime} \mathrm{N} 31^{\circ} 14^{\prime} \mathrm{W}$. Buoyancy frequencies were calculated in $100 \mathrm{~m}$ thick layers, from ensemble-averaged profiles in the southern and northern basins.

imum potential density observed in the Lucky Strike rift valley during our survey $\left(\sigma_{2}=36.919\right.$ at $\left.37^{\circ} 08.0^{\prime} \mathrm{N} 32^{\circ} 19.2^{\prime} \mathrm{W} 2785 \mathrm{~m}\right)$ occurs in the 1983 data at $1900( \pm 100) \mathrm{m}$. The horizontal gradients of salinity and oxygen on this isopycnal in the 1983 data are dominated by their meridional components, with the oxygen concentration increasing and the salinity decreasing toward the north, while there are no significant corresponding zonal gradients. Given the large isopycnal salinity changes that have occurred in this latitude band in the North Atlantic over the last few decades (Curry et al., 2003) it is not a priori clear how much the regional isopycnal hydrographic gradients have changed since 1983. It is noted, however, that meridional salinity gradients of similar magnitude were also observed between $30^{\circ}$ and $40^{\circ} \mathrm{N}$ on the same isopycnal in the CLIVAR A16N \& A20 repeat hydrography sections occupied in 2003 along $20^{\circ}$ and $52^{\circ} \mathrm{W}$, respectively.

\section{b. Rift-Valley Hydrography}

Consistent with observations from many other similar deep submarine valleys (Saunders and Francis, 1985; Thurnherr and Richards, 2001; Thurnherr and Speer, 2003) the water in the rift valley at Lucky Strike is considerably less dense and stratified than the water at the same depth on the ridge flanks (Fig. 3); this effect is due to blocking at the inflow sills and diapycnal mixing within the valley. In our survey data the hydrographic transition between the rift valley and the overlying water column occurs near $1800 \mathrm{~m}$, i.e. close to the depth of the deepest sills on the rift-valley 


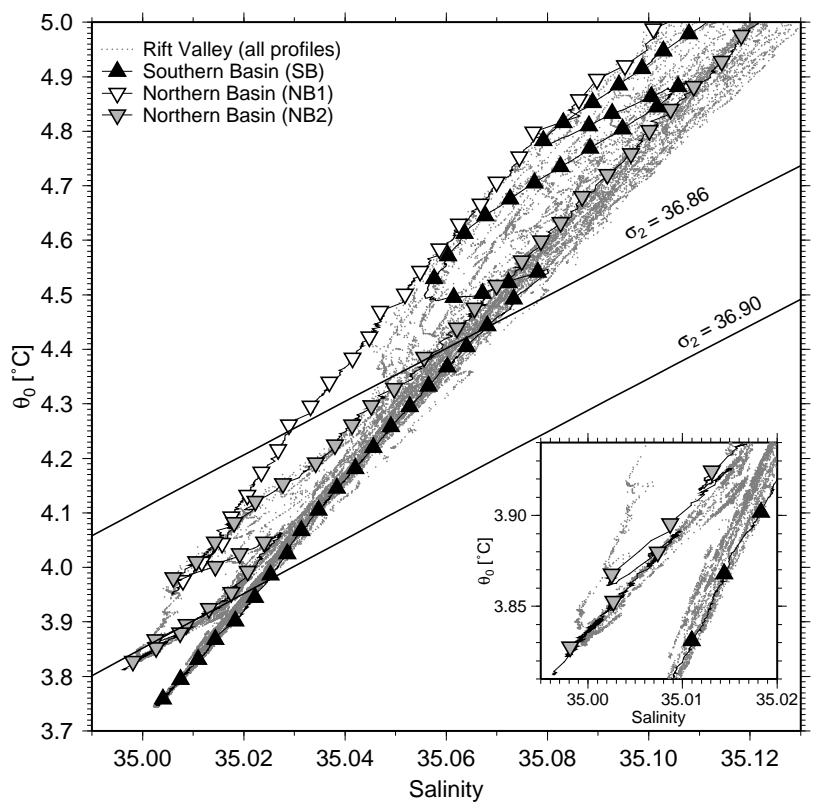

Figure 4: T/S properties in the rift valley; the inset shows a zoomed view illustrating the nearseabed properties in the northern basin (see text for details). Three example profiles discussed in the text are marked with symbols.

walls in this region (Fig. 1). Within the rift valley, the density profiles separate into two distinct populations below $\approx 2200 \mathrm{~m}$. Inspection of the individual profiles reveals that all high-density profiles were collected south of the segment center in the southern basin and all lower-density profiles in the northern basin. As a consequence, the deep stratification is weaker in the northern than in the southern basin (Fig. 3, right panel). In both deep basins the stratification near the seabed is very weak, with the buoyancy frequency in the northern basin below $2600 \mathrm{~m}$ approaching the local value of the Coriolis parameter $\left(f \approx 9 \times 10^{-5} \mathrm{~s}^{-1}\right)$.

The T/S properties of the rift-valley water are bracketed by warm/salty and cold/fresh end members, both with approximately linear (and parallel) T/S characteristics (Fig. 4). There is a single profile from the northern basin at $37^{\circ} 25^{\prime} \mathrm{N} 32^{\circ} 25^{\prime} \mathrm{W}$ where only the cold/fresh end member was sampled (labeled "NB1" in the figure). At all other stations both cold/fresh and warm/salty water was observed, often in multiple vertically alternating layers characterized by salinity "steps" of 0.01-0.02 (e.g. profiles "SB" \& "NB2"). Similar interleaving signatures have been observed in the rift valley of the MAR before, both in the Lucky Strike segment (Wilson et al., 1996) and elsewhere (e.g. near $36^{\circ} 15^{\prime} \mathrm{N}$; Thurnherr and Richards, 2001). Inspection of individual profiles with interleaving layers indicates that the cold/fresh water is associated with higher levels of dissolved oxygen than the warm/salty water. Combining the isopycnal salinity difference between the two water-mass end members observed in the Lucky Strike segment $(\approx 0.03)$ with the meridional salinity gradient on the $36.919 \sigma 2$-isopycnal in the TOPOGULF/3 data between $36^{\circ}$ and $39^{\circ} \mathrm{N}\left(\approx-1.5 \times 10^{-4} \mathrm{~km}^{-1}\right)$ implies that the warm/salty/oxygen-rich water enters the rift valley 

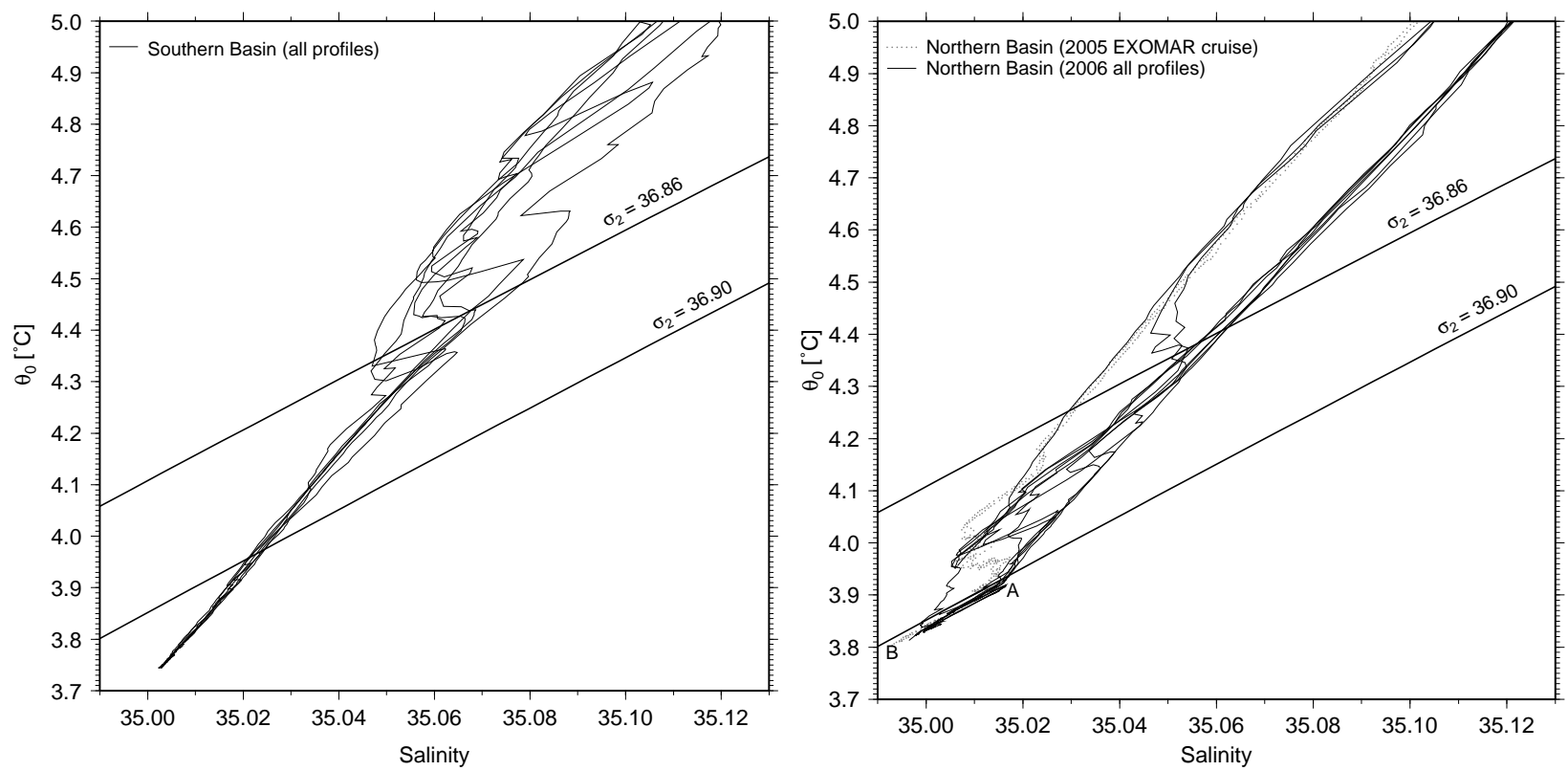

Figure 5: T/S properties in the deep southern and northern basins. Left panel: Southern basin; right panel: Northern basin, including data from a station occupied in 2005 (EXOMAR cruise); see text for explanation of labels "A" and "B".

$\approx 200 \mathrm{~km}$ south of the cold/fresh/oxygen-poor water. Below, we will use the terms "northernorigin" and "southern-origin" to differentiate between the two water masses.

In order to elucidate the spatial distribution of the water masses in the Lucky Strike segment it is useful to distinguish different density layers: At potential densities below 36.86 (corresponding to depths shallower than 1700 and $1660 \mathrm{~m}$ in the southern and northern basins, respectively) both southern- and northern-origin waters are found throughout our survey region (Fig. 5). Below this isopycnal the southern basin contains only water of southern origin (left panel). In the northern basin, the mix of southern- and northern-origin water extends all the way to the seabed (right panel). Approximately one year prior to our survey, two CTD profiles were collected in the northern basin (star in Fig. 2) with the same CTD that was used a year later on the Pourquoi Pas ?. Comparison between the 2005 and 2006 data indicates that there was no significant change in the hydrographic properties (Fig. 5, right panel). The T/S properties in the northern basin below $\sigma_{2}=36.90(\approx 2100 \mathrm{~m})$ are particularly interesting: With a single exception (one of 4 profiles collected near $37^{\circ} 24^{\prime} \mathrm{N} 32^{\circ} 15^{\prime} \mathrm{W}$ ), all deep northern-basin profiles show a transition between southern-origin warm/salty water at $\sigma_{2}=36.90$ (labeled "A" in the right panel of Fig. 5) and northern-origin cold/fresh water at the bottom (labeled "B"). In most profiles this transition involves interleaving layers, as illustrated by example profile "NB2" in the inset of Figure 4. 


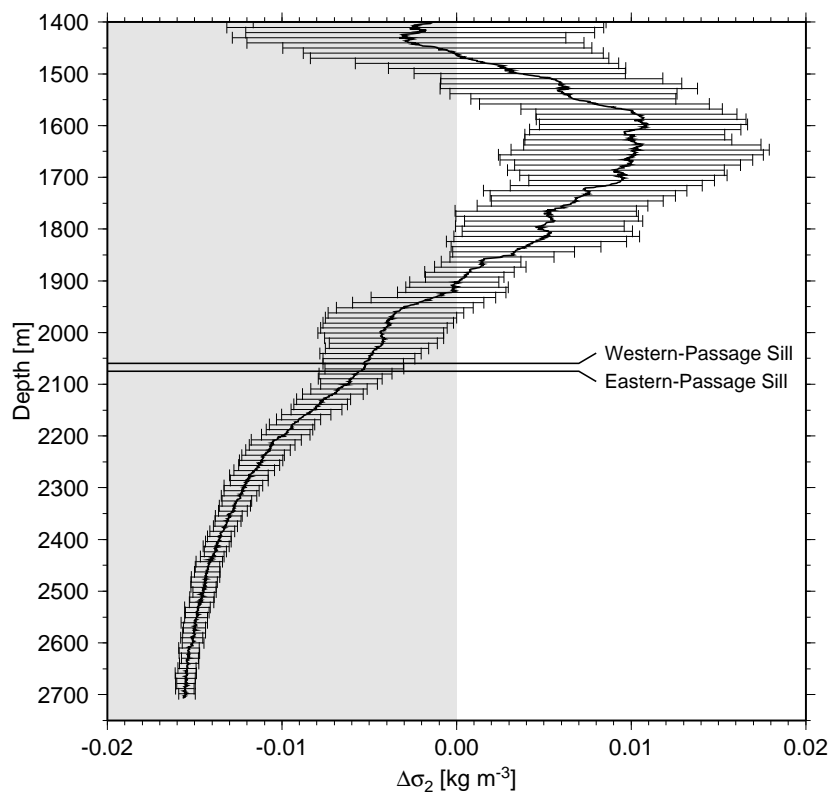

Figure 6: Potential-density differences between the northern and southern basins; error bars show standard deviations; negative values (shaded half space) indicate northward-decreasing densities; the sill depths in the two deep passages on either side of the Lucky Strike seamount are marked.

\section{c. Rift-Valley Circulation}

In order to quantify the along-segment potential-density gradients (Fig. 3), ensemble averages were calculated from the 10 available CTD profiles in the northern and from the 7 profiles in the southern basin, ignoring depths with less than 5 samples. The isobaric density differences between these mean profiles are characterized by two distinct layers, a lower one between $1900 \mathrm{~m}$ and the seabed, where the density decreases toward the north, and an upper one between 1500 and $1900 \mathrm{~m}$, where the density increases toward the north (Fig. 6). Similar vertical dipoles of along-valley density gradients are commonly observed in deep submarine valleys; in a steady state they are maintained by a balance between unidirectional along-axial advection (down-gradient in the lower layer) and strong diapycnal mixing (Thurnherr and Speer, 2003). One particularly relevant example is found at another rift-valley site, approximately $200 \mathrm{~km}$ south of Lucky Strike, where there is a vertical density-gradient dipole across a persistent overflow transporting $\approx 0.1 \mathrm{~Sv}$ of rift-valley water to the north and where the diapycnal diffusivities near the overflow are of order $10^{-2} \mathrm{~m}^{2} \mathrm{~s}^{-1}$ (Thurnherr, 2006).

As expected from the sign of the along-valley density gradient below $1900 \mathrm{~m}$, the deep flow in the Lucky Strike rift valley during GRAVILUCK was predominantly to the north (Fig. 7). The observed currents near the seabed are strong, in particular in the eastern passage where the mean northward velocity is $\approx 10 \mathrm{~cm} \mathrm{~s}^{-1}$ with some values downstream of the sill exceeding $20 \mathrm{~cm} \mathrm{~s}^{-1}$. The available velocity, hydrographic and mixing (microstructure) observations from the eastern passage are consistent with a hydraulically controlled overflow extending from the seabed at least 


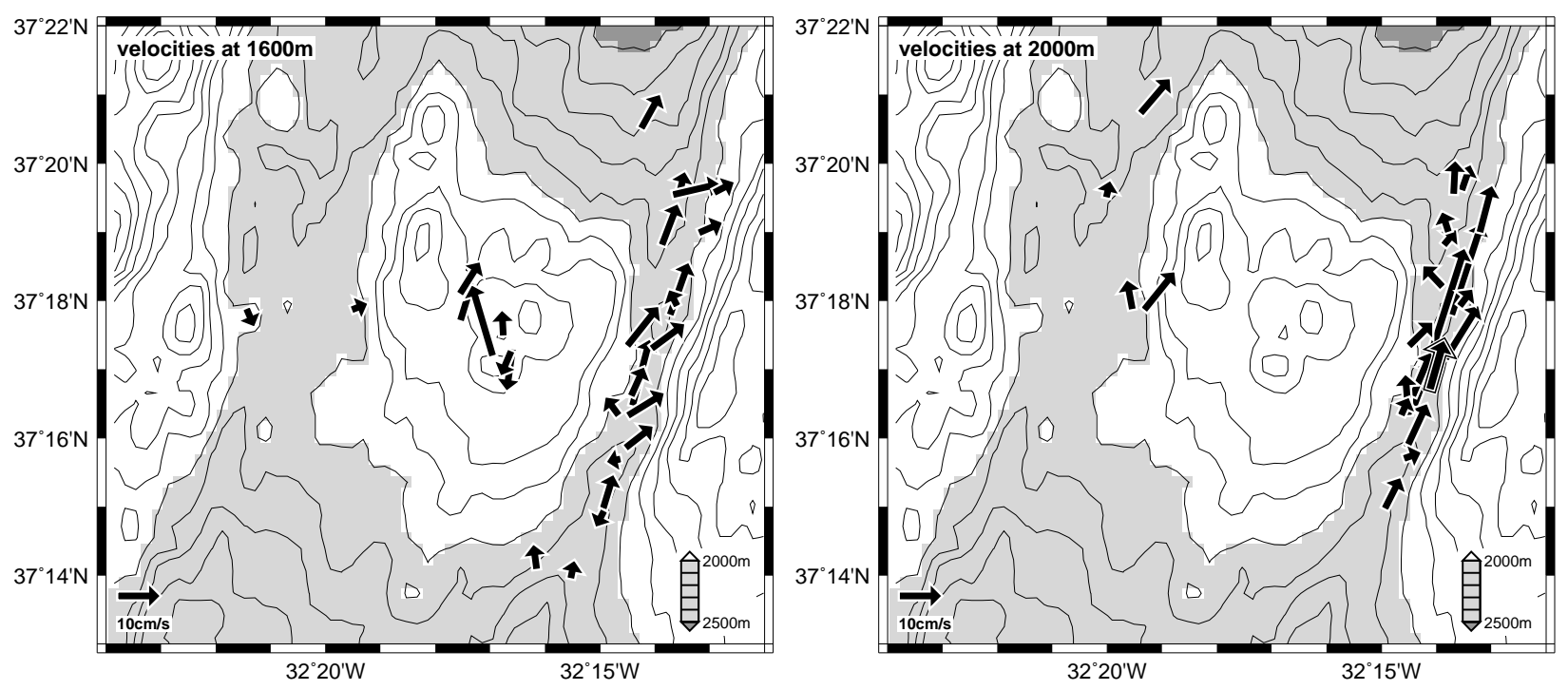

Figure 7: $50 \mathrm{~m}$ layer-averaged velocities centered at $1600 \mathrm{~m}$ (left panel) and $2000 \mathrm{~m}$ (right panel). Black arrows: LADCP velocities that are significantly different from zero (speed $>$ inversionderived error estimate). Double arrow in right panel near $37^{\circ} 17^{\prime} \mathrm{N} 32^{\circ} 14.5^{\prime} \mathrm{W}$ : 2-week averaged velocity from the bottom-mounted ADCP. Topographic contour interval is $100 \mathrm{~m}$.

up to $1800 \mathrm{~m}$ (St. Laurent and Thurnherr, 2007). While sampling limitations prevent a definite conclusion, it appears that the deep flow in the western passage is similar but somewhat weaker.

The maximum potential density observed at a station near the northern (downstream) end of the eastern passage $\left(\sigma_{2}=36.9034\right.$ at $\left.37^{\circ} 20^{\prime} \mathrm{N} 32^{\circ} 14^{\prime} \mathrm{W} 2154 \mathrm{~m}\right)$ provides an estimate for the maximum density of the water flowing into the northern basin from the south. The transit time for flow through the passages $\left(\tau_{t}=l / \bar{u} \approx 28 \mathrm{hr}\right.$, where $l \approx 10 \mathrm{~km}$ is the passage length and $\bar{u} \approx 10 \mathrm{~cm} \mathrm{~s}^{-1}$ is the mean along-passage velocity) is similar to but somewhat longer than a pendulum day at this latitude $\left(\tau_{f}=2 \pi / f \approx 20 \mathrm{hr}\right.$ ), indicating that rotational effects play a role in the overflow dynamics. The relevant Rossby radius is $\approx 5 \mathrm{~km}$ (from $N h / f$, where $N=1.1( \pm 0.3) \times 10^{-3} \mathrm{~s}^{-1}$ is the buoyancy frequency and $h \approx 400 \mathrm{~m}$ is the vertical extent over which the passages are laterally closed). The fact that the eastern passage is narrower than the deformation radius is consistent with the lack of any apparent cross-passage shear of the along-passage flow. The width of the western passage is similar to the deformation radius, but our sampling is insufficient to determine whether there is a significant cross-valley shear of the along-axial flow there.

The apparent dominance of the "mean" flow over the variability in the deep eastern passage is quantitatively confirmed by kinetic-energy spectra calculated from the two-week-long record of the bottom-mounted ADCP deployed there: Motions with periods longer than $56 \mathrm{hr}$ (including the mean flow) were over six times more energetic than the semidiurnal tides, which dominated the higher-frequency variability and were associated with $r m s$ velocities of $4.6 \mathrm{~cm} \mathrm{~s}^{-1}$. The time-series data furthermore indicate that southward near-bottom flow in the eastern passage occurred less than $3 \%$ of the time, consistent with the LADCP data where southward flow near the seabed is observed in only one out of the 18 available profiles from the eastern passage. 

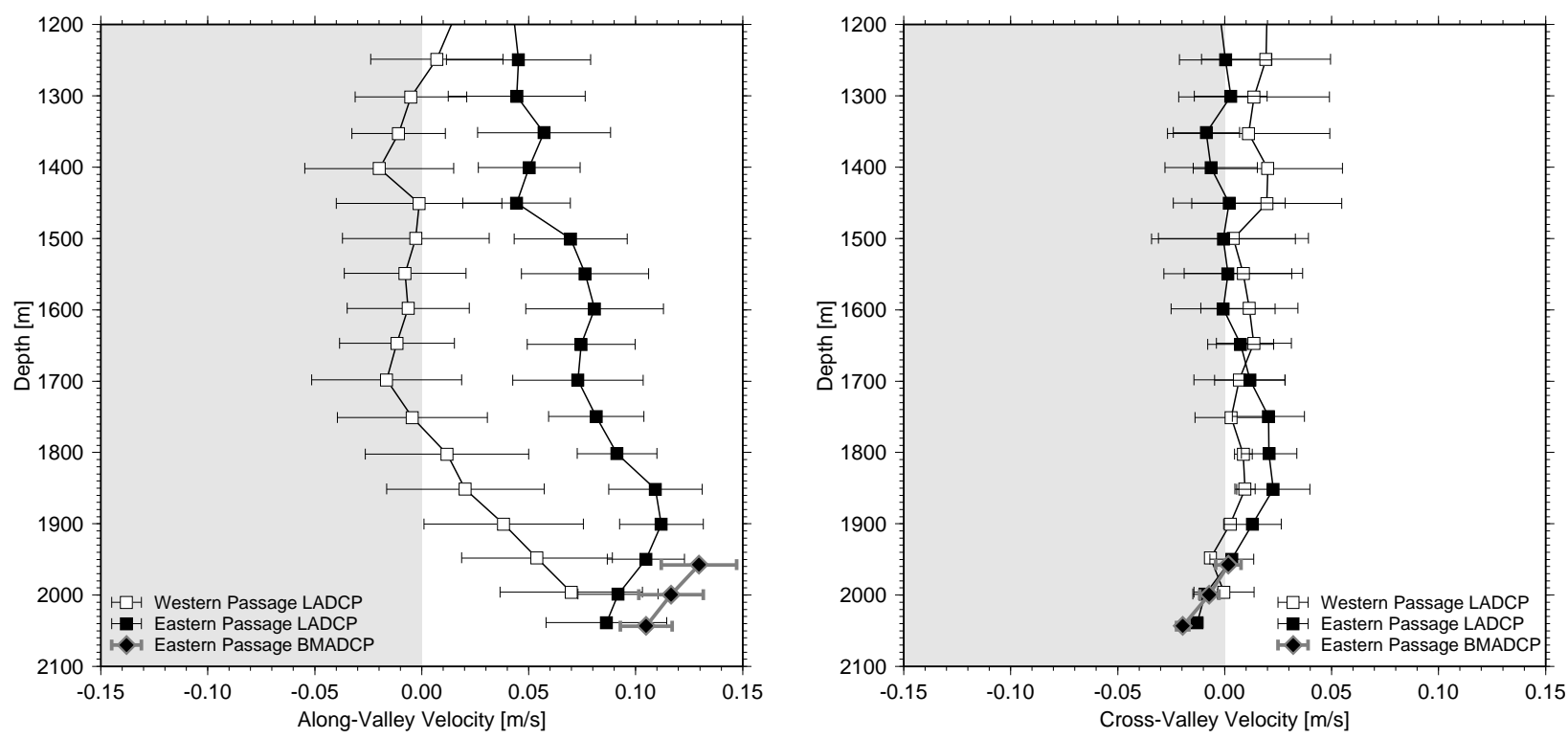

Figure 8: Ensemble-averaged velocity profiles near the sills in the deep passages on both sides of the Lucky Strike volcano; negative half spaces are shaded. Left panel: along-channel velocities $\left(20^{\circ}\right.$ true); right panel: cross-channel velocities $\left(110^{\circ}\right.$ true). The western-passage LADCP average is derived from 3 profiles; that from the eastern passage from 4, and the bottom-mounted ADCP (BMADCP) recorded velocities for 14 days. Error bars show standard errors of the means, assuming sample independence for individual LADCP profiles and semi-diurnal tidal dominance of the variability for the bottom-mounted ADCP data.

Above the overflows at $1600 \mathrm{~m}$ the instantaneous velocities recorded by the LADCP are characterized by greater variability and the dominance of northward flow is restricted to the eastern part of the rift valley (Fig. 7, left panel). No coherent circulation was observed over the Lucky Strike seamount, where two out of the 6 LADCP profiles with significant velocities at $1600 \mathrm{~m}$ show southward flow. Since the (arbitrarily referenced) $\mathrm{M}_{2}$ phases of the two profiles associated with southward flow at $1600 \mathrm{~m}$ are similar to each other $\left(232^{\circ}\right.$ and $\left.266^{\circ}\right)$, but considerably different from the phases of the other four profiles $\left(52^{\circ}, 54^{\circ}, 172^{\circ}\right.$ and $355^{\circ}$ ), we interpret the variability apparent in the LADCP measurements as primarily caused by the tides, rather than by spatial variability. This inference is consistent with the long-term current-meter records from the center of the Lucky Strike volcano, which confirm significant probabilities for both north- and southward flows throughout the entire durations of the records (rightmost column in Table 1).

\section{d. Along-Segment Transport}

In order to remove the effects of tidal variability as much as possible, ensemble-averaged velocity profiles were calculated from the available LADCP data near the controlling sills in the eastern and western passages (Fig. 8). The deep cross-sill flows in both passages are northward with time-averaged speeds near the seabed of $5-10 \mathrm{~cm} \mathrm{~s}^{-1}$. Significant northward velocities in the 


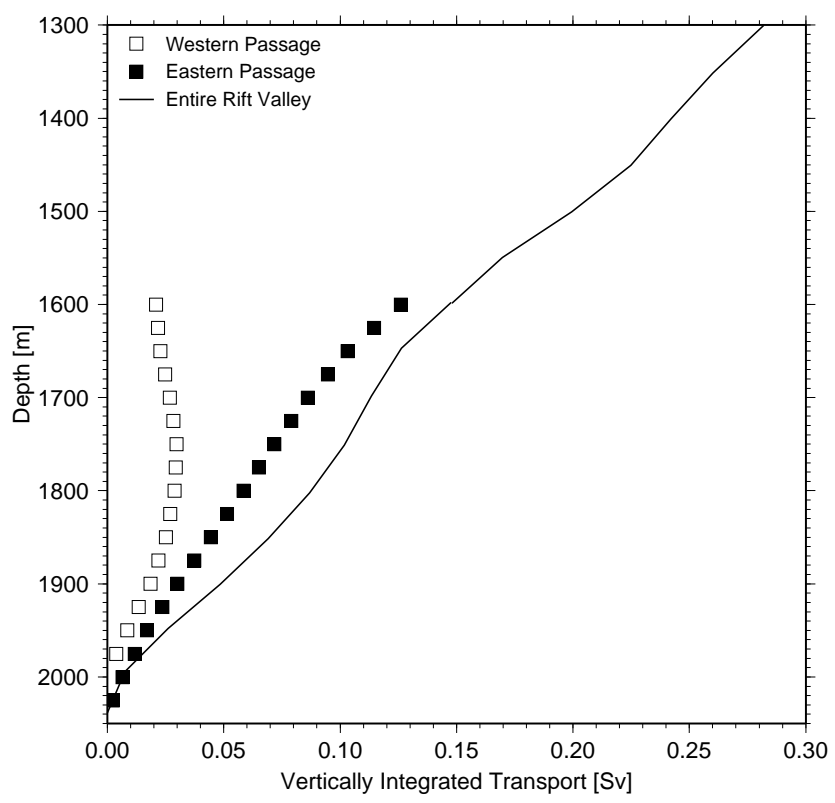

Figure 9: Vertically integrated along-valley transport calculated from the mean velocity profiles in the two deep passages (Fig. 8) and the rift-valley cross section at $37^{\circ} 18^{\prime} \mathrm{N}$. Below $1600 \mathrm{~m}$, separate transports were calculated for the eastern and western passages; above $1600 \mathrm{~m}$, the eastern and western velocity profiles were averaged and integrated over the entire width of the rift-valley.

eastern passage extend throughout the entire depth of the rift valley, whereas the northward flow in the western passage is restricted to depths below $1800 \mathrm{~m}$. Above $1900 \mathrm{~m}$ the ensemble-averaged LADCP velocities in the western passage are not significantly different from zero; however, the data are suggestive of a weak mean southward return flow above $1750 \mathrm{~m}$. As expected, the crosschannel velocities are significantly smaller than the corresponding along-channel velocities. The monotonic vertical shears in the cross-channel velocities below $1850 \mathrm{~m}$ observed in both deep passages are consistent with observations from other overflows and are most likely the signatures of bottom Ekman layers (Johnson and Sanford, 1992), supporting our previous inference that rotational effects play a role in the overflow dynamics (Section 3c).

Combining the mean along-passage velocities with the rift-valley geometry at the latitude of the controlling sills yields an estimate of the along-valley transport (Fig. 9). Below $1800 \mathrm{~m}$, the northward flows in both passages contribute significantly to the total while the currents in and above the eastern passage dominate the along-valley transport at shallower depths.

\section{Hydrothermal Particle Plumes}

Neutrally buoyant hydrothermal plumes resulting from high-temperature venting are rich in particles and, therefore, associated with significant light-scattering anomalies that can sometimes be traced several 10s of $\mathrm{km}$ from their sources (e.g. Thurnherr and Richards, 2001). The distribu- 


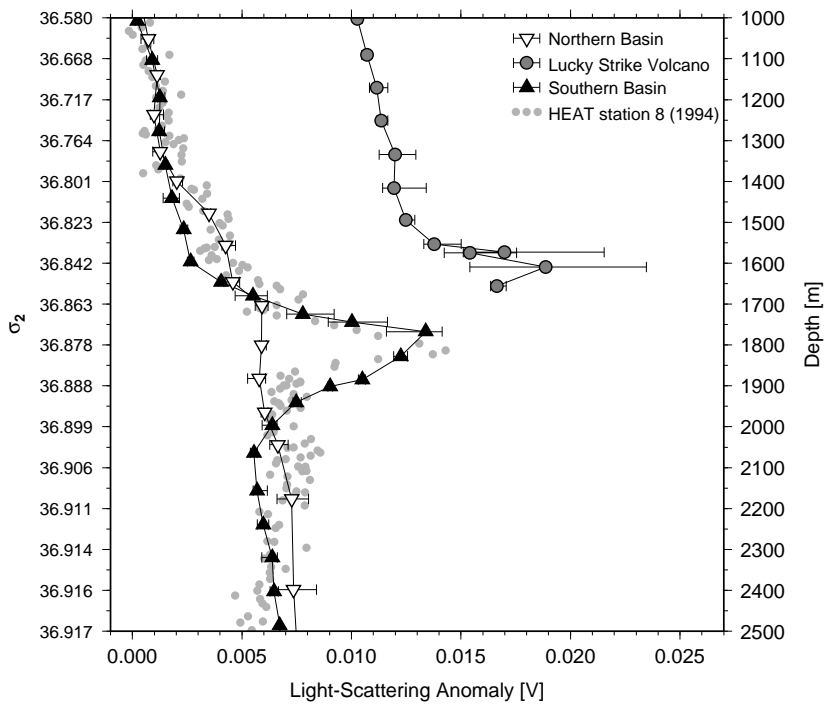

Figure 10: Lucky Strike light-scattering (STM) anomalies in density space. The right-hand y-axis indicates the mean depths of the isopycnals in the southern basin. The three profiles with error bars show density-averaged GRAVILUCK light-scattering anomalies in the southern basin, over the Lucky Strike volcano, and in the northern basin, respectively; the corresponding stations are enclosed by grey dashed circles in Figure 2. For clarity, the profile from the volcano has been horizontally offset by $0.01 \mathrm{~V}$. The error bars show the minimum and maximum values in each density bin. The light-grey dots show an the arbitrarily scaled nephelometry profile occupied in 1994 near the southern end of the segment (pentagon in Fig. 2; German et al., 1996).

tion of the light-scattering anomalies in the Lucky Strike rift valley observed during GRAVILUCK is characterized by a generally downward-increasing trend on which the distinct peaks of neutrally buoyant hydrothermal particle plumes are superimposed (Fig. 10). Outside the hydrothermal plume peaks the particle load below $\approx 1400 \mathrm{~m}$ in the northern basin is consistently higher than the corresponding particle load at the same densities in the southern basin.

Whereas no distinct hydrothermal-plume signatures were observed north of the Lucky Strike volcano during GRAVILUCK, the three light-scattering profiles from the deep southern basin (as well as a subset of the eastern-passage profiles) show a $\approx 400 \mathrm{~m}$-thick plume centered near the 36.878 isopycnal $(\approx 1800 \mathrm{~m})$. A nephelometry profile collected in 1994 near the southern end of the segment is associated with a distinct light-scattering peak in the same density range (grey dots in Fig. 10). While the different light-scattering instruments used during the 1994 HEAT cruise and GRAVILUCK preclude a quantitative comparison, the qualitative similarities between the 1994 plume and our southern-basin observations nevertheless suggest a common source. Both the fact that no northern-origin water was observed during GRAVILUCK in the southern basin below $1700 \mathrm{~m}$ (Section $3 \mathrm{~b}$ ) and the observed northward along-valley transport in the depth range of this plume (Fig. 9) imply a source south of the southernmost of the GRAVILUCK light-scattering stations. While buoyant high-temperature hydrothermal plumes rise rapidly from their sources, light- 
scattering anomalies nevertheless commonly extend all the way to the source depth (e.g. Thurnherr and Richards, 2001). Therefore, we surmise that the most likely depth of the unknown hydrothermal vent field in the south of the Lucky Strike segment is $\approx 2000 \mathrm{~m}$.

During GRAVILUCK, optical anomalies associated with the hydrothermal plumes rising from the known vents at Lucky Strike were observed directly over the Lucky Strike seamount (Fig. 10). The fact that this segment-center plume occupies a different density range than the southern-basin plume supports our inference of two separate sources. Averaging the light-scattering profiles in pressure or depth space yields the same conclusion: The southern-basin plume peaks at $1800 \mathrm{~m}$, $\approx 150 \mathrm{~m}$ deeper than the segment-center plume. These observations are consistent with the fact that the along-segment density differences in the depth range of the plumes $(<0.01$; Fig. 6$)$ are small compared to the density difference between the two plume peaks $(\approx 0.03$; Fig. 10). Apart from the profiles collected directly over the Lucky Strike seamount, no hydrothermal particle anomalies were observed in the density range of the segment-center plume elsewhere in our survey region.

\section{Discussion}

\section{a. Synthesis of Observations}

The observations of the rift-valley hydrography and velocity field at Lucky Strike obtained during GRAVILUCK indicate a remarkably simple dynamical setting, characterized by mean flow toward the north and a vertical dipole of along-stream horizontal density gradients. Below $1900 \mathrm{~m}$ the density decreases along the path of the flow, while there is a streamwise density increase of similar magnitude between 1500 and $1900 \mathrm{~m}$. The strongest along-valley flow was observed in the deep passages on both sides of the Lucky Strike seamount where the cross-sectional area of the rift valley is smallest. The observed cross-sill density drop below $1900 \mathrm{~m}$ is consistent with hydraulic control, as inferred from a detailed analysis of the CTD, LADCP and microstructure data from the eastern passage by St. Laurent and Thurnherr (2007). Above the summit depth of the Lucky Strike seamount the northward flow takes place in a boundary current along the eastern rift-valley wall. Within the two overflows and in the boundary current above the eastern passage the low-frequency currents are stronger than the temporal variability, while the semidiurnal tide dominates the instantaneous velocity field over the Lucky Strike seamount and above the western passage. Overall, these observations are highly reminiscent of the situation in the rift valley in the vicinity of the Rainbow hydrothermal vent field near $36^{\circ} \mathrm{N}$, where similarly strong northward flow and a corresponding vertical dipole of along-segment density gradients are associated with a hydraulically controlled overflow and strong mixing (Thurnherr and Richards, 2001; Thurnherr et al., 2002; Thurnherr, 2006).

Combined, the two overflows in the Lucky Strike segment center transport $\approx 0.2 \mathrm{~Sv}$ of riftvalley water toward the north. Approximately half of this southern inflow into the northern basin takes place below $1800 \mathrm{~m}$, where the basin is entirely closed, implying that at least $0.1 \mathrm{~Sv}$ of overflow water must upwell within the basin, again similar to the situation in the rift valley near $36^{\circ} \mathrm{N}$ (Thurnherr et al., 2002). However, the presence of northern-origin water near the seabed in all hydrographic profiles from the northern basin (both in 2005 and 2006) implies an additional source 
for the densest water observed there. This inference is supported by the close agreement between the isopycnal marking the upper limit of the transition between southern- and northern-origin water in the northern basin $\left(\sigma_{2} \approx 36.90\right.$; Section $\left.3 \mathrm{~b}\right)$ and the densest water observed near the downstream end of the eastern passage $\left(\sigma_{2}=36.9034\right.$; Section 3c). The most likely inflow location for the northern-basin bottom water is the deepest sill connecting the rift valley to the western MAR flank near $38^{\circ} \mathrm{N} 32^{\circ} 45^{\prime} \mathrm{W}$ (labeled "A" in Fig. 1). We surmise, therefore, that, on average, the sill in the northwestern corner of the northern basin acts as an additional inflow, rather than as an outflow and, thus, that significantly more than $0.1 \mathrm{~Sv}$ of water upwell in the northern half of the Lucky Strike segment.

\section{b. Hydrothermal Particle Plumes \& Their Sources}

The simplicity of the circulation in the Lucky Strike segment encountered during GRAVILUCK allows us to infer the source locations of the hydrothermal particle plumes with much greater confidence than has been possible in previous studies. We observed two distinct hydrothermal particle plumes, one between 1700 and $2000 \mathrm{~m}$ in the southern basin and in the eastern passage, and the other over the summit of the Lucky Strike volcano below $1580 \mathrm{~m}$. The known vents at Lucky Strike are almost certainly the source of the latter, implying a mean plume rise of $\approx 100 \mathrm{~m}$ during our survey. The apparent reduction in rise height compared to the FAZAR data collected in 1992 (Wilson et al., 1996) may indicate a reduction in heat flux or a change in effluent chemistry. Given the predominantly northward flow within the segment, as well as the fact that the light-scattering maximum in the southern basin $(1800 \mathrm{~m})$ was observed below the depth of the known vents at Lucky Strike $(1700 \mathrm{~m})$, we conclude that the southern-basin plume emanates from a separate, notyet-discovered hydrothermal source south of the Lucky Strike volcano. ${ }^{4}$ The depth range of the southern-basin light-scattering plume observed during GRAVILUCK coincides closely with that of a single plume profile recorded in 1994 in the rift valley approximately $25 \mathrm{~km}$ south of the Lucky Strike volcano (German et al., 1996), suggesting the same hydrothermal source, most likely near the southern end of the Lucky Strike segment at $\approx 2000 \mathrm{~m}$.

In contrast to the segment center and the southern basin, we did not observe any particle-plume signatures north of the Lucky Strike volcano, in spite of the fact that both the particles from the Lucky Strike vents and from the southern source are advected there by the mean flow. The apparent "disappearance" of the hydrothermal particles is most likely due to the strength of the diapycnal mixing in the deep passages (St. Laurent and Thurnherr, 2007), spreading the hydrothermal particles throughout the entire depth of the rift valley. This inference is supported by the observation that, outside the depth range of the southern-source plume, the light scattering in the rift valley below $1400 \mathrm{~m}$ is consistently higher in the northern than in the southern basin.

There are several possible reasons why the southern-source plume was observed several 10s of kilometers from its likely source while the plume emanating from the Lucky Strike hydrothermal field was only observed within a kilometer from the vents. First, it is possible that the mixing between the southern source and the Lucky Strike segment center is too weak to effectively "mix

\footnotetext{
${ }^{4}$ The southern-basin plume is also too deep to be related to the somewhat mysterious "Menez Hom" site, which, according to Jean-Baptiste et al. (2008), is a low-temperature source located at a latitude of $37^{\circ} 08^{\prime} \mathrm{N}$ near $1790 \mathrm{~m}$.
} 
away" the particle plume before it reaches the overflows. Second, chemical differences between the effluents of the two sources may either cause the southern-source plume to precipitate significantly more particles than the plume rising from the Lucky Strike vents or the southern-source particles may be more neutrally buoyant than the Lucky Strike particles, resulting in less settling. Finally, it is also possible of course that the southern source is associated with significantly higher heat and chemical fluxes than the Lucky Strike vent field. While we do not have any evidence for such a difference we note that the only other known particle plume that can be traced several 10s of kilometers from the corresponding source in the rift-valley of the MAR occurs at the Rainbow hydrothermal vent field, which is associated with significantly higher fluxes of heat (Thurnherr and Richards, 2001; Jean-Baptiste et al., 2004) and particles (Khripounoff et al., 2001) than the Lucky Strike vents (Wilson et al., 1996).

\section{c. Representativeness of the Survey Data For Longer Timescales}

There is significant circumstantial evidence suggesting that the deep flow in the Lucky Strike rift valley was northward not just in 2006, but also during all other surveys we are aware of (in 1992, 1994 and 2005), i.e. that the GRAVILUCK observations are representative for the flow on much longer time scales. First, we reiterate that the interleaving signatures observed in the rift-valley T/S properties both in 2005 and 2006 require two distinct water sources meridionally separated by several hundreds of kilometers (Section $3 b$ ) and, therefore, unidirectional advection along a considerable stretch of rift valley. While the MAR topography precludes advection into the Lucky Strike segment below $1800 \mathrm{~m}$ from the north, the deep rift valley extends continuously south to the Oceanographer fracture zone near $35^{\circ} \mathrm{N}$. Therefore, we infer that northward flow in the rift valley of the Lucky Strike segment in 2005 and 2006 is required in order to account for the observed interleaving signatures. Wilson et al. (1995) also discuss interleaving in the Lucky Strike segment and a comparison of their Figure 8 (or Figure 2 of Wilson et al., 1996) to our Figure 4 indicates that the interleaving signatures observed in 1992 are qualitatively and quantitatively very similar to ours, i.e. they also require northward flow in the rift valley. While German et al. (1996) do not discuss the rift-valley hydrography an inspection of their CTD data reveals nevertheless that interleaving signatures of very similar magnitude were also observed in 1994, again implying northward flow. Furthermore, the available hydrothermal-plume data from 1992 and 1994 are also fully consistent with northward flow in the rift valley, as the Lucky Strike vents are too shallow to account for the plumes observed south of the Lucky Strike volcano below $1700 \mathrm{~m}$ (Klinkhammer et al., 1995; Wilson et al., 1996; German et al., 1996).

The inference of northward rift-valley flow in 1992 is strongly supported by a hydrographic section along the axis of the MAR, which is characterized by a monotonic northward density decrease below $1800 \mathrm{~m}$ between $35^{\circ} 40^{\prime} \mathrm{N}$ and the northernmost deep rift-valley station at $37^{\circ} \mathrm{N}$, i.e. the monotonic density gradient spans the South AMAR, AMAR, FAMOUS, and North FAMOUS segments (Wilson et al., 1995). It requires predominantly northward flow as there is no mechanism that could cause a streamwise densification of the bottom water in a laterally enclosed valley. The data suggest, therefore, that the northward velocities observed during our survey are part of a coherent along-valley flow that begins $\approx 250 \mathrm{~km}$ south of Lucky Strike. Direct evidence for long-term 


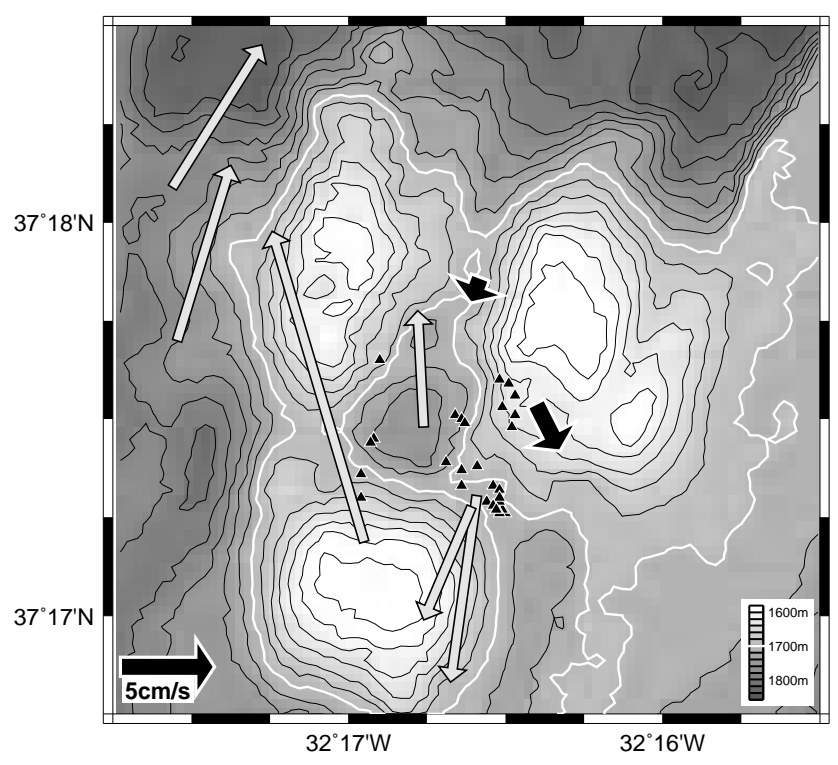

Figure 11: Velocity observations at $1600 \mathrm{~m}$ around the eastern group of peaks of the Lucky Strike volcano. Topographic contour interval is $20 \mathrm{~m}$; the $1700 \mathrm{~m}$ isobath is marked with a white contour. Wide black arrows show record means of the available long-term current-meter data (Table 1). Narrow gray arrows show the GRAVILUCK LADCP data, which are dominated by the semidiurnal tides at this location (Section 3c). Small black triangles mark the locations of the currently known hydrothermal sources (J. Escartín, personal communication).

persistence of this larger-scale northward flow in the rift valley is provided by current-meter data from the FAMOUS segment near $36^{\circ} 45^{\prime} \mathrm{N}$, where continuous strong northward flow was observed during a 46-day deployment in 1972 (Keller et al., 1975), and from the Rainbow hydrothermal site at $36^{\circ} 15^{\prime} \mathrm{N}$, where persistent strong northward along-valley flow was observed on two sets of moorings deployed for an entire year in 1997/98 (Khripounoff et al., 2001; Thurnherr et al., 2002). The observation in 1998 of an inflow into the rift valley from the eastern North Atlantic near $35^{\circ} 35^{\prime} \mathrm{N}$ $34^{\circ} 10^{\prime} \mathrm{W}$ (Thurnherr et al., 2002), i.e. approximately $250 \mathrm{~km}$ south of the Lucky Strike vent field, is fully consistent with our inferences.

During our survey the northward flow at Lucky Strike extended significantly above $1600 \mathrm{~m}$ where two current meters deployed on the summit of the volcano had recorded southward yearlong mean flows in 1994/95 and 2001/02 (Table 1 \& Fig. 11). While this apparent difference in mean-flow direction could be attributed to interannual variability, it should be noted that the northward flow at this depth during our survey took place primarily in a boundary current along the eastern wall of the rift valley, whereas individual velocity samples over the summit of the volcano were dominated by the semidiurnal tide (Section 3c). Therefore, there is no contradiction between our LADCP data from the summit of the Lucky Strike volcano and the available year-long current-meter records. This inference is supported by the observation of both south- and northward two-week-averaged mean velocities throughout the entire 1994/95 current-meter record, northward 
flow accounting for $\approx 30 \%$ of the 2 -week averages. Therefore, it is not possible to determine the direction of the yearly averaged low-frequency flow over the summit of the Lucky Strike volcano at $1600 \mathrm{~m}$ from our 2-week survey.

In contrast to the 1994/95 data, the longest run of northward mean daily averaged flow in the 2001/02 current-meter record lasted only 3 days. The fact that these data were recorded in close proximity to the seabed ( $15 \mathrm{~m}$ above bottom) suggests that nearby topography may have affected the velocities. Topographic influence is also suggested by the close alignment of the yearly-averaged mean-flow directions of both current-meter records with nearby topographic contours (Fig. 11), which is qualitatively consistent with a cyclonic (counterclockwise) recirculation around the easternmost peak of the Lucky Strike volcano. The GRAVILUCK data are insufficient to determine whether such a re-circulation existed in August 2006.

\section{d. Larger Context \& Implications}

All available data that we are aware of indicate that the overflows in the Lucky Strike segment are part of a contiguous persistent northward rift-valley flow that extends $\approx 250 \mathrm{~km}$ to the south (Section 5c). This flow field has important consequences for the dispersal of hydrothermal organisms between the vent sites in this region of the MAR, as northward advection is strongly favored. For example, a sufficiently long-lived demersal larva released into the rift valley at the Rainbow hydrothermal field near $36^{\circ} 15^{\prime} \mathrm{N}$ can conceivably settle at Lucky Strike (or at any of the intervening vent fields), whereas dispersal in the opposite direction is much less probable.

The depth of the MAR crest in this region decreases toward the north, because of the influence of the Azores hotspot; i.e. the water in the rift valley flows uphill. Considering also the high rates of diapycnal mixing in the valley both at Lucky Strike (St. Laurent and Thurnherr, 2007) and further south (Thurnherr et al., 2002), the rift-valley dynamics are highly reminiscent of the situation in numerous canyons corrugating the western flank of the MAR in the South Atlantic, where there are persistent low-frequency up-flank flows down the density gradients and high rates of diapycnal mixing (St. Laurent et al., 2001; Thurnherr et al., 2002; Thurnherr et al., 2005). It is also worth noting that both in the rift valley and in one relatively well sampled ridge-flank canyon in the South Atlantic a significant portion of the diapycnal mixing appears to be associated with overflows (Thurnherr et al., 2002; Thurnherr et al., 2005; Thurnherr, 2006; St. Laurent and Thurnherr, 2007), which suggests that overflow mixing may be much more important for closing the overturning circulation than is generally accepted. Regardless, however, to what degree the diapycnal fluxes taking place on the rough mid-ocean ridge topography are associated with hydraulic processes, such overflows are ideal monitoring sites. Simultaneously instrumenting, for example, several distant overflows in the same valley would allow both the integrated diapycnal and the vertical fluxes between the overflows to be determined.

ACKNOWLEDGMENTS. We highly appreciate the shiptime offered to us by V. Ballu, chief scientist of the GRAVILUCK project, as well as instrumental and personnel support from DT-INSU. The officers and crew of the French research vessel L'Atalante, as well as the Nautile submersible team enthusiastically supported our efforts and ensured the scientific success of our project. The 
survey work was funded by the US National Science Foundation under grant \#0550730, with additional support from the French IDAO/LEFE GRAVILUCK project. Free access to data from earlier expeditions provided by A. Godfroy, C. Wilson and C. German is gratefully acknowledged.

\section{References}

Baker, E. T. and C. R. German. 2004. On the global distribution of hydrothermal vent fields, in Mid-Ocean Ridges: Hydrothermal Interactions Between the Lithosphere and Oceans, Geophysical Monograph Series, 148, C. R. German, J. Lin, and L. M. Parson, eds., 245-266.

Cannat, M., A. Briais, C. Deplus, J. Escartín, J. Georgen, J. Lin, S. Mercouriev, C. Meyzen, M. Muller, G. Pouliquen, A. Rabain, and P. da Silva. 1999. Mid-Atlantic Ridge-Azores hotspot interactions: Along-axis migration of a hotspot-derived event of enhanced magmatism 10 to 4 Ma ago. Earth Planet. Sci. Lett., 173, 257-269.

Converse, D. R., H. D. Holland, and J. M. Edmond. 1984. Flow rates in the axial hot springs of the East Pacific Rise $\left(21^{\circ} \mathrm{N}\right)$ : Implications for the heat budget and the formation of massive sulfide deposits. Earth Planet. Sci. Lett., 69, 159-175.

Curry, R., B. Dickson, and I. Yashayaev. 2003. A change in the freshwater balance of the Atlantic Ocean over the past four decades. Nature, 426, 826-829.

Elderfield, H. and A. Schultz. 1996. Mid-ocean ridge hydrothermal fluxes and the chemical composition of the ocean. Annu. Rev. Earth Planet. Sci., 24, 191-224.

German, C. R., E. T. Baker, and G. Klinkhammer. 1995. Regional setting of hydrothermal activity. Geol. Soc. London Spec. Publ., 87, 3-15.

German, C. R., L. M. Parson, and the HEAT Scientific Team. 1996. Hydrothermal exploration at the Azores triple-junction: Tectonic control of venting at slow-spreading ridges? Earth Planet. Sci. Lett., 138, 93-104.

Gould, W. J.. 1985. Physical oceanography of the Azores front. Prog. Oceanogr., 14, 167-190.

Harvey, J. and M. Arhan. 1988. The water masses of the central North Atlantic in 1983-84. J. Phys. Oceanogr., 18, 1855-1875.

Herring, P.. 2002. The Biology of the Deep Ocean. Oxford University Press.

Jean-Baptiste, P., H. Bougault, A. Vangriesheim, J. L. Charlou, J. Radford-Knoery, Y. Fouquet, D. Needham, and C. German. 1998. Mantle ${ }^{3} \mathrm{He}$ in hydrothermal vents and plume of the Lucky Strike site (Mid-Atlantic Ridge $36^{\circ} 17^{\prime} \mathrm{N}$ ) and associated geothermal heat flux. Earth Planet. Sci. Lett., 157, 69-77.

Jean-Baptiste, P., E. Fourré, J.-L. Charlou, C. R. German, and J. Radford-Knoery. 2004. Helium isotopes at the Rainbow hydrothermal site (Mid-Atlantic Ridge, 36:14N). Earth Planet. Sci. Lett., 221, 325-335. 
Jean-Baptiste, P., E. Fourré, A. Dapoigny, J. L. Charlou, and J.-P. Donval. 2008. Deepwater mantle ${ }^{3} \mathrm{He}$ plumes over the northern Mid-Atlantic Ridge $\left(36^{\circ} \mathrm{N}-40^{\circ} \mathrm{N}\right)$ and the Azores Platform. Geochem. Geophys. Geosyst., 9, Q03010.

Johnson, G. C. and T. B. Sanford. 1992. Secondary circulation in the Faroe Bank Channel outflow. J. Phys. Oceanogr., 22, 927-933.

Keller, G. H., S. H. Anderson, and J. W. Lavelle. 1975. Near-bottom currents in the Mid-Atlantic Ridge rift valley. Can. J. Earth Sci., 12, 703-710.

Khripounoff, A., T. Comtet, A. Vangriesheim, and P. Crassous. 2000. Near-bottom biological and mineral particle flux in the Lucky Strike hydrothermal vent area (Mid-Atlantic Ridge). J. Mar. Syst., 25, 101-118.

Khripounoff, A., A. Vangriesheim, P. Crassous, M. Segonzac, A. Colaco, D. Desbruyeres, and R. Barthelemy. 2001. Particle flux in the Rainbow hydrothermal vent field (Mid-Atlantic Ridge): Dynamics, mineral and biological composition. J. Mar. Res., 59, 633-656.

Khripounoff, A., A. Vangriesheim, P. Crassous, M. Segonzac, V. Lafon, and A. Warén. 2008. Temporal variation of currents, particulate flux and organism supply at two deep-sea hydrothermal fields of the Azores Triple Junction. Deep Sea Res. I:, 55, 532-551.

Klinkhammer, G. P., C. S. Chin, C. Wilson, and C. R. German. 1995. Venting from the MidAtlantic Ridge at $37^{\circ} 17^{\prime} \mathrm{N}$ : The Lucky Strike Hydrothermal Site. Geol. Soc. London Spec. Publ., 87, 87-96.

Langmuir, C., S. Humphris, D. Fornari, C. VanDover, K. VonDamm, M. K. Tivey, D. Colodner, J. L. Charlou, D. Desonie, C. Wilson, Y. Fouquet, G. Klinkhammer, and H. Bougault. 1997. Hydrothermal vents near a mantle hot spot: The Lucky Strike vent field at $37^{\circ} \mathrm{N}$ on the Mid-Atlantic Ridge. Earth Planet. Sci. Lett., 148, 69-91.

McDuff, R. E.. 1995. Physical dynamics of deep-sea hydrothermal plumes, in Seafloor Hydrothermal SystemsS. E. Humphris, R. A. Zierenberg, L. S. Mullineaux, and R. E. Thomson, eds., Physical, Chemical, Biological, and Geological Interactions.

Mullineaux, L. S., P. H. Wiebe, and E. T. Baker. 1995. Larvae of benthic invertebrates in hydrothermal vent plumes over Juan-de-Fuca Ridge. Marine Biology, 122, 585-596.

Otto, T. D. and A. M. Thurnherr. 2007. Efficient algorithms for finding sills in digital topographic maps. Computers and Geosciences, 33, 678-684.

Saunders, P. M. and T. J. Francis. 1985. The search for hydrothermal sources on the Mid-Atlantic Ridge. Prog. Oceanogr., 14, 527-536.

St. Laurent, L. C., J. M. Toole, and R. W. Schmitt. 2001. Buoyancy forcing by turbulence above rough topography in the abyssal Brazil Basin. J. Phys. Oceanogr., 31, 3476-3495.

St. Laurent, L. C. and A. M. Thurnherr. 2007. Intense mixing of lower thermocline water on the crest of the Mid-Atlantic Ridge. Nature, 448, 680-683. 
Sy, A.. 1988. Investigation of large-scale circulation patterns in the central North Atlantic: The North Atlantic Current, the Azores Current, and the Mediterranean Water plume in the area of the Mid-Atlantic Ridge. Deep Sea Res., Part A, 35, 383-413.

Thurnherr, A. M. and K. J. Richards. 2001. Hydrography and high-temperature heat flux of the Rainbow hydrothermal site ( $36^{\circ} 14^{\prime} \mathrm{N}$, Mid-Atlantic Ridge). J. Geophys. Res., 106, 94119426.

Thurnherr, A. M., K. J. Richards, C. R. German, G. F. Lane-Serff, and K. G. Speer. 2002. Flow and mixing in the rift valley of the Mid-Atlantic Ridge. J. Phys. Oceanogr., 32, 1763-1778.

Thurnherr, A. M. and K. G. Speer. 2003. Boundary mixing and topographic blocking on the Mid-Atlantic Ridge in the South Atlantic. J. Phys. Oceanogr., 33, 848-862.

Thurnherr, A. M., L. C. St. Laurent, K. G. Speer, J. M. Toole, and J. R. Ledwell. 2005. Mixing associated with sills in a canyon on the mid-ocean ridge flank. J. Phys. Oceanogr., 35, 13701381.

Thurnherr, A. M.. 2006. Diapycnal mixing associated with an overflow in a deep submarine canyon. Deep Sea Res. II, 53, 194-206.

Wilson, C., K. Speer, J.-L. Charlou, H. Bougault, and G. Klinkhammer. 1995. Hydrography above the Mid-Atlantic Ridge $\left(33^{\circ}-40^{\circ} \mathrm{N}\right)$ and within the Lucky Strike segment. J. Geophys. Res., 100, 20,555-20,564.

Wilson, C., J. L. Charlou, E. Ludford, G. Klinkhammer, C. Chin, H. Bougault, C. German, K. Speer, and M. Palmer. 1996. Hydrothermal anomalies in the Lucky Strike segment on the Mid-Atlantic Ridge $\left(37^{\circ} 17^{\prime} \mathrm{N}\right)$. Earth Planet. Sci. Lett., 142, 467-477. 